\title{
Risk Management and Its Impact on the Performance of Insurance Companies: The Case of Kosovo
}

\author{
Msc. Myhybije Zallqi Zhara
}

Email:lirafesta1@hotmail.com

Prof. Ass. Dr. Ibish Mazreku

Email: ibishmazreku@yahoo.com

Doi:10.5901/ajis.2014.v3n2p293

\begin{abstract}
Experience of successful businesses in the insurance field has shown that risk management provides wealth preservation and growth, enhancing reputation regardless of scope, taking into account the fact that the risk is not only a threat, but it also presents opportunities if the insurance company is prepared in time to handle it adequately. International studies show that insurance companies with good risk management have better return on equity and better performance in other key business indicators in comparison with competitors who do not give great importance to risk management. This study will use structured questionnaires to explore the extent of the application of risk management in insurance companies in Kosovo and its impact on their business performance. Also, the annual reports of companies are used to see the financial performance of companies. The hypothesis of this study relates to the impact of risk management in the financial performance of companies participating in the study. Thus, it can be understood that the information provided may present the situation of the sector and behavior of the insurance market in Kosovo in terms of risk management policies and how they influenced modern risk management in the company's financial performance in the insurance market of Kosovo. Hence, these data can be of great interest to any other local companies to prompt them to put risk management at the top of their agenda when it is known that in this area remain behind shell companies in the region and EU 's.
\end{abstract}

Keywords: Risk management, Insurance companies, Performance, Insurance market.

\section{Introduction}

In the last decade in Kosovo insurance market has gone through an important stage of its development and consolidation. And now, it can be said that has reached at a very pleasing level of development and as such can provide highly qualitative services for the citizens of the Republic of Kosovo. This is indicated by increased performance from year to year, which has been reflected by the increasing number of contracts and the increased volume of premiums. However, it should be mentioned that this sector still has challenges ahead to achieve higher qualitative services, further increasing security offers and contemporary products and, especially, in perfecting methods and risk managemen, in order to achieve the highest possible performance in business and also the application of European standards in this field.

The main goal in this research paper is to bring out a brief study on the development of the insurance sector in Kosovo, especially, on the importance of the development of risk management in insurance companies and their performance.

In particular, it will be sought the understanding of : the justification of the practice of risk management by companies, development of risk management in terms of improving risk management functions and development process of risk management, and how all these issues are influenced by the type of each insurance company in Kosovo .

\subsection{Scientific-practical contribution of the research}

This study has a great importance because in practical terms, primarily, helps all managers of the risk of insurance companies that have been selected for analysis.

The results of this study would be a modest contribution with regard to the wide area of risk management, particularly, in the insurance sector and could help managers of these companies through the arguments and results of 
this study, which should be subject to further discussions and studies in the field of insurance.

\section{A Brief History of the Insurance Market in Kosovo}

It has been over 13 years since the insurance market has resumed work in Kosovo. After the war in Kosovo as well as any other business sector, the insurances have faced the problems of the beginning of their activities, because almost everything started from zero. The first security regulation, which starts functioning in Kosovo, is Regulation No. 3 of UNMIK, 1999. After this order, in Kosovo have been registered the first companies to exert the insurance activity.

There are a total of 13 insurance companies operating in Kosovo, 10 of which provide non-life insurance, while, the other three operate in the life insurance sector . During 2013 there have been changes in terms of ownership of companies, where, a company of non-life insurance from foreign ownership has passed in local ownership. Consequently , the number of insurance companies that are in the local ownership is increased to 4 , while, 9 companies remain in the foreign ownership.

The percentage of assets of insurance companies that are owned by foreigners has been decreased to 66 percent from 71 percent that was in June 2012.

Fig. 1 - Insurance Companies in Kosovo

The insurance market in Kosovo offers the following types of insurance:

- Forced Insurance

- Voluntary insurance, and

- Border security.

\section{Current Developments}

Insurance sector activity continued to increase during the first half of 2013. Assets of insurance companies are increased annually by 8.3 percent, reaching 130.1 million euros. Nevertheless, the system of insurance companies has continued to expand the activities, the share of the insurance system in the financial sector as a whole is $3.4 \%$.

Table 1. The insurance market in 2012 and the percentage comparison to 2011

\begin{tabular}{|l|r|r|r|r|r|}
\hline Ianar - Dhjetor & \multicolumn{2}{|c|}{ Bruto Primi I Shkruar } & \multicolumn{1}{c|}{ Indexi } & \multicolumn{2}{r|}{ Pjesa ndaj totalit ne (\%) } \\
\hline Kompania & $\mathbf{2 0 1 1}$ & $\mathbf{2 0 1 2}$ & R12/R11\% & $\mathbf{2 0 1 1}$ & $\mathbf{2 0 1 2}$ \\
\hline Illyria & $15,712,099$ & $11,038,238$ & $-29.75 \%$ & $22.95 \%$ & $16.52 \%$ \\
\hline Dardania & $5,202,202$ & $9,332,405$ & $79.39 \%$ & $7.60 \%$ & $13.96 \%$ \\
\hline Sigal Uniqa & $8,735,404$ & $9,237,464$ & $5.75 \%$ & $12.76 \%$ & $13.82 \%$ \\
\hline Siguria & $6,967,446$ & $9,227,294$ & $32.43 \%$ & $10.18 \%$ & $13.81 \%$ \\
\hline Sigma & $7,574,391$ & $7,110,987$ & $-6.12 \%$ & $11.07 \%$ & $10.64 \%$ \\
\hline Elsig & $7,196,595$ & $6,581,945$ & $-8.54 \%$ & $10.51 \%$ & $9.85 \%$ \\
\hline Kosova e Re & $5,426,606$ & $4,780,088$ & $-11.91 \%$ & $7.93 \%$ & $7.15 \%$ \\
\hline Insig & $6,235,009$ & $3,981,925$ & $-36.14 \%$ & $9.11 \%$ & $5.96 \%$ \\
\hline SigKos & $2,467,224$ & $2,825,838$ & $14.54 \%$ & $3.60 \%$ & $4.23 \%$ \\
\hline Croatia & $2,934,322$ & $2,713,864$ & $-7.51 \%$ & $4.29 \%$ & $4.06 \%$ \\
\hline Gjithsej & $\mathbf{6 8 , 4 5 1 , 2 9 8}$ & $\mathbf{6 6 , 8 3 0 , 0 4 8}$ & $-2.37 \%$ & $\mathbf{1 0 0 . 0 0 \%}$ & $\mathbf{1 0 0 . 0 0 \%}$ \\
\hline
\end{tabular}

Figure 1. Graphic insurance market distributed by companies

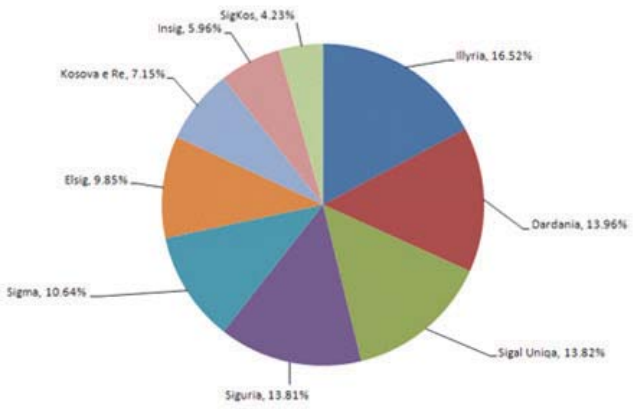


The activity of insurance companies has been increased. In June 2013, the total number of policyholders sold by insurance companies amounted to 459.5 thousand compared to 306.3 thousand policies in the same period of the previous year. Besides increasing the number of policyholders, also has been increased the total gross written premiums. Their value in June 2013 amounted to 40.5 million euros, representing an annual growth of 14.3 percent (see Chart 2).

Figure 2. Written premiums and paid claims in euros (2013)

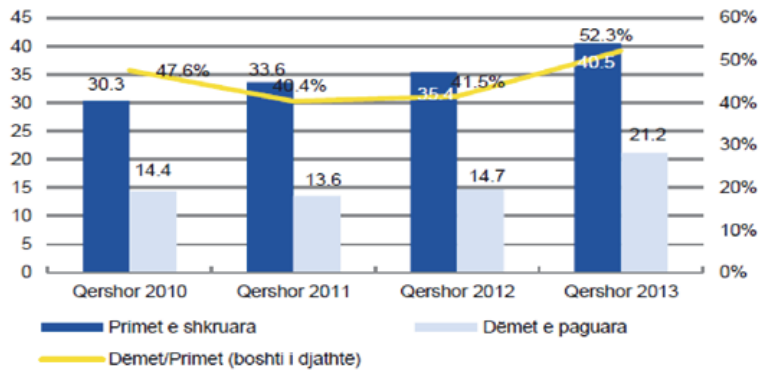

Paid claims by the insurance companies for this period have marked a significant annually increase of 44 percent. The value of total gross paid claims in June 2013 amounted to EUR 21.2 million compared with 14.7 million in the previous year. A higher growth rate of paid claims during the first half of 2013 has affected the relationship between paid claims and insurance premiums rise to 52.3 percent from 41.5 percent in June 2012. The paid claims and the annual administrative costs ( at the rate of 25 percent ) have affected the sector to record loss despite the increase of activity.

The losses of the sector until June 2013 amounted 1.4 million euros, while in the same period of the previous year the sector had achieved net profit of 0.7 million euros. This led that the performance indicators such as Return on Average Asets : ROAA and Return on Average Equity: ROAE, have negative values. ROAA in June 2013 was -0.57 compared with 0.62 percent in June 2012 , while ROEE was -3.09 percent compared with 1.5 percent in June 2012.

\section{Risk Management in Insurance System}

Insurance is related to risk reduction and protection against financial loss from adverse events . " Insurance company with such loss-sharing among a large group, reduces the risk faced by the individual party providers '.

The nature of the activity of an insurance company is to take the risk of its policyholders in exchange for a premium, and insurance companies take these risk as a way to profit. Essential elements of the risk management process in the insurance companies include "merging and the distribution of risk, control exposures and providing adequate protection through reinsurance.".

According to the study conducted by (KPMG , 2002), in most cases, the cause for the bankruptcies of insurance companies has not been to a single factor, but rather due to a combination of internal and external factors. A common reason for bankruptcy of an insurance company is a combination of poor quality management procedures and inadequate risk management dealing with major risks to which the company is exposed. This fact highlights the need for adequate internal models to assist in the process of risk management..

In insurance companies, risk management procedures as well as the overall quality of management are considered as important factors and together with sufficient financial resources are key factors in protecting against an insurance company insolvency . In addition, the process of effective risk management should cover all key elements of the business cycle and, more importantly to adequately manage the risks to which the company is exposed, it should:

Risk management needs to be more transparent in how risk is identified and managed : According to (Lam , 2003)

- understand what risk management is and what is its composition that should include basic knowledge of probability;

- to know the overall risk figure by identifying different categories of risks that must be managed;

- to recognize the strength of the risk, the risk that defines the boundaries between those who are willing to bear the same and those who are not willing to bear this risk;

- to make the process of formal risk management; 
- to develop a culture of risk, each one within the community should be able to identify and manage the risk. Most of them are not able, because they have not enough knowledge or culture related to it. The critical success factor is the generation and maintenance of a culture of risk management;

- learn from their successes or failures;

- utilize risk assets and risk models to support the decision-making process;

- to accept that risk management is closely related to innovation, which are vital for long-term operation of an organization.

In the narrowest sense, risk management includes the following activities : the risk identification, risk assessment and treatment (management) and then, the monitoring of events or activities, which may cause losses - in most cases financial loss.

This means that risk management is an active process, which requires ongoing commitment and focus on the problems. But, in most cases, lack adequate information and data to the same risks that can accurately define and that hinder the process and requires greater diligence. For this reason, many commitments are made for modeling and risk assessment.

\section{Solvency}

Solvency margin is a necessary level in the assets of a company that covers a theoretical capital required by the regulator. Respectively, the solvency is the ability of an insurance company to pay damages that may occur in the future. This means that the insurer must have sufficient assets to meet obligations, but also to satisfy the statutory financial requirements.

The approach of Solvency II regarding risk management emphasizes finite responsibility of senior managers for all risk management activities. Organizations are encouraged to establish risk management functions, the implementation of legal requirements, internal audit and actuarial operations processes to enable appropriate risk management.

In the insurance industry in Kosovo, are set some certain restrictions on assets by CBK, which states that " all insurers and branches of foreign insurers must maintain a solvency margin calculated as total assets (excluding unacceptable assets) minus liabilities (by shareholder 's equity), which should be higher than the Minimum Solvency Margin" and this restriction is made so that assets are of good quality, and this limitation can be defined as Available Solvency Margin - ASM). Another essential element in assessing the financial health of an insurance company is its level of capital in relation to its risk profile, in other words, the adequacy of its capital. moreover, an important element is the adequacy of provisions for compensation claims expected to be made. These provisions may be called:
i. Insurance liabilities
ii. Actuarial liability
iii. Policy on reserves
iv. Policy on obligations
v. Actuarial Fund
vi. Technical provisions

\section{Measuring the Performance of Insurance Corporates}

Owners, i.e shareholders are interested on saving, increasing and returning of the invested capital as well as the amount that would be realized from the capital invested. Therefore, the relevant measures of the performance that show :

1. Rate of return of invested capital - ROI

2. Rate of return of principal property - ROE

3. Profit per share - EPS

4. Dividends per share - DPS

The most common measure of corporate performance utilizing the security (in terms of profit) is ROI . This is a result of the relationship between net income before tax and the total assets .

The advantages of this measure are:

- The review of the impact of all that has happened; summary;

- A good way of assessing the worthiness of the investment project;

- Provide stimulating efficient use of assets, as well as achieving a stimulates new assets when there are chances that it will increase the rate of return; 
The shortcomings of this measure are:

- It is quite sensitive to the policy of depression (depreciation);

- It is sensitive to the value of accounting;

Other popular measures are EPS and ROE, but even though, these have certain shortcomings, therefore, are not counted as favorable for measuring corporate performance.

$\mathrm{ROI}, \mathrm{ROE}$ and EPS are considered classic measures of corporate performance, which are not adequate, so for them are needed proxies . In fact, it is considered that these indicators, based on the accounting data are not reliable indicators of the value of the corporate economy.

\section{Discussion and Analysis of Results}

To analyze the extent and effects of the application of risk management in the performance of the insurance sector in Kosovo, it has been used traditional methods of research, specifically, this study has been done through questionnaires, interviews and reports from the relevant institutions. The questionnaires have been distributed to the participants of this study in person by the researcher and also through electronic communications.

The overall research has involved a sample of five registered companies, because other companies have not been responded either electronically or in our in person contacts. Although, the target companies to be included in the study are all licensed in Kosovo ( total 13 ), the number of five companies that asnewered the questionnaire is relatively small. As a result, it should be paid attention on attempting to generalize the findings of this paper. Regarding the performance of the companies, the annual reports have been analyzed and compared and high -level managers have been interviewed in these companies.

Table 2. Characteristics of the participating insurance companies in the research

\begin{tabular}{|l|c|c|c|c|c|}
\hline Insurance Company & Year & Number of Employees & Number of offices & Life Insurance & Non-life Insurance \\
\hline K.S. Illyria & 2002 & 193 & 51 & X & $\sqrt{ }$ \\
\hline K.S. Dardania & 2000 & 150 & 60 & $X$ & $\sqrt{ }$ \\
\hline K.S. Sigal & 2003 & 135 & 53 & $\sqrt{ }$ & $\sqrt{ }$ \\
\hline K.S. Kosova e Re & 2002 & 140 & 60 & $X$ & $\sqrt{ }$ \\
\hline K.S. Marina & 2010 & 22 & 2 & $\sqrt{ }$ & $\sqrt{ }$ \\
\hline
\end{tabular}

The table shows that the IC " Illyria " and IC " Dardania " are two insurance companies with the largest number of empoyees, which are operating only on the non-life insurance market. Also, these are among the first companies licensed to operate in the Kosovo's insurance market. If you see table no. 1 . presented above on, we find that even in the separation of the market of two companies, leads IS " Illyria " that is 16:52 \% share market, followed by the IC" Dardania " with $13.96 \%$.

The respondents' opinions on "do the insurance companies share a part of their budget on risk control" are separated in this way , $60 \%$ of companies answered YES that a part of their budget it is shared for risk control versus 40 $\%$ of the companies answered NO .

A total of $80 \%$ of companies that responded to the survey consider that the most common strategy used by them to control risk is " There are special personnel , who are integrated in different areas of the company ." On the other hand, $20 \%$ of companies consider that the strategy used by them is that " There is not a specific personnel assigned to control risk." The results of the answers to this question are presented in the chart below.

Figure 3. The strategy of companies to control risk

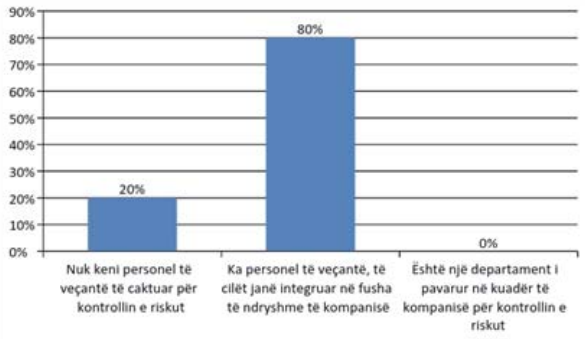


Through the question "Do your company know the Solvency II and its instructions? it has been tried to understand the level of knowledge of the companies on Solvency II which is also called solvency and means the ability of a company to cover its long-term obligations. The responses of the companies participating in the study have been almost the same, where, all answered "Yes" indicates that Kosovo's companies know what Solvency II is, but that the application of this EU model for risk management is not at the desired level to these companies. Based on the financial reports of 2012, the total calculated solvency of the insurance industry was 13.7 million euros, declining from $25 \%$ compared to the previous year 2011.

Table 3. Calculation of minimum solvency margin (non-life companies)

\begin{tabular}{|l|c|c|}
\hline Activity & $\mathbf{2 0 1 1}$ & $\mathbf{2 0 1 2}$ \\
\hline Total: Assests & 102.1 & 110.4 \\
\hline Minus: non-acceptable assets & -12.5 & -15.5 \\
\hline = Neto Assests & 89.6 & 94.9 \\
\hline Minus: Liabilities excluding net assets & -65.2 & -75.2 \\
\hline The level of the minimum solvency margin & 6.0 & 6.0 \\
\hline Level of Solvency & 18.4 & 13.7 \\
\hline Solvency Position & Solvent & Solvent \\
\hline
\end{tabular}

The decline in solvency compared with the previous year's growth comes as a result of unacceptable assets under regulative effect on the one hand and growth on the other obligations.

In the next question: "To whom risk is reported, from the organizational point of view (check one option)? It has been penetrated deeper into the recognition of organizational structure in the field of risk management, particulary, being more interested in risk reporting hierarchy. None of the interviewed companies did not have a special manager risk control, but, according to the data obtained, it appears that each of the companies report to different levels of management.

Table 4. Answers to the question "to whom companies report on the risk"

\begin{tabular}{|l|c|}
\hline To whom risk is reported by the companies & percentage \\
\hline Chief Executive Officer (CEO) & $32 \%$ \\
\hline Chief Financial Officer (CFO) & $17 \%$ \\
\hline Management control officer & $17 \%$ \\
\hline Technical Director & $17 \%$ \\
\hline Management and Board & $17 \%$ \\
\hline
\end{tabular}

Figure 4. Answers to the question of "to whom is reported the risk of organizational standpoint?

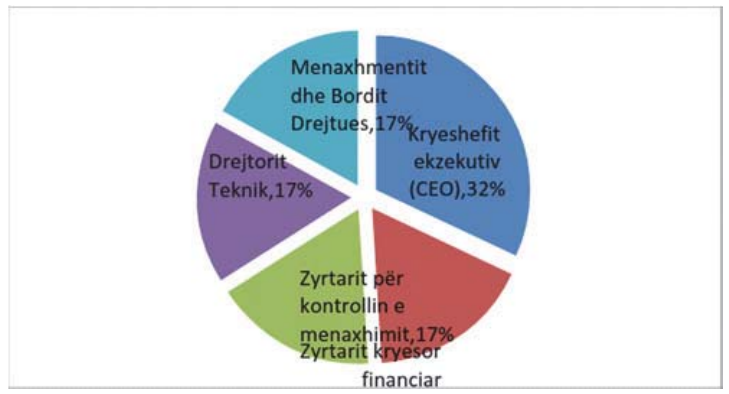

The question "What are the calculations used for risk management in your company? It is noticed to the companies to understand more about the methods that use the companies participating in the study to calculate the risk. The data demonstrates that Kosovo insurance companies use different methods to calculate risk and such methods are presented in the following table.

As it is known from theoretical approach, insurance companies calculate risk through various methods in which the 
most important are: Mixed Methods, Benchmark Method, Stress test method, Deterministic method, Parametric method and Simulation Method. Also, the objective of Solvency II is that risk calculation methods should be adaptable to the development of risk profiles in the company.

Table 5. The answer to the question "which companies use calculations for risk management"

\begin{tabular}{|l|c|}
\hline Calculations used for risk management & percentage \\
\hline Mixed & $43 \%$ \\
\hline Benchmark & $29 \%$ \\
\hline Stress Test & $14 \%$ \\
\hline Deterministic & $0 \%$ \\
\hline Parametric & $0 \%$ \\
\hline Simulation & $14 \%$ \\
\hline
\end{tabular}

Based on the responses, it is seen that almost half of the companies respectively $43 \%$ used mixed methods for calculating the risk, whereas, among other methods, as a most used method appears to be the benchmark by $29 \%$ and then, with equal percentage are simulation method and method of stress test which participate with equal percentage of $14 \%$ each .

Hence, based on the responses given by the five insurance companies and analysis made in this section can be concluded that " insurance companies that have better performance in the insurance market in Kosovo have the best practices of risk management than the companies that have lower performance in this insurance market ". This is evidenced partially, considering the small number of the research sample and the market almost evenly distributed between insurance companies, therefore, can not be said that the hypothesis is fully certified.

Thus, based on the replies given to the questions indicate that there cannot be differences between companies that have high performance and those that have lower insurance performance in Kosovo regarding risk management practices.

\section{Conclusions}

Findings from this study suggest that the demands of regulatory and supervisory authorities may have a significant effect on the insurance companies to help improve their practice of the risk management, which is very important for the proper development of all insurance industry in Kosovo .

Data from the study of risk management shows that is the impact of contemporary risk management in insurance companies, despite the problems that are as a result of the lack of experience and the transition phase that our country is facing.

It can be also emphasized that the performance of the insurance market in Kosovo was good based on the annual reports of CBK, although, the risk management practices are still not at a satisfactory level and do not have proper attention by the management of these companies.

The study conducted on risk management of insurance companies in Kosovo is the first of its kind and the results of this study claim that is a modest contribution in terms of this broad area of risk management with particular emphasis on insurance companies that can help managers of the companies. The results of this study are limited based on the perspective of completing the questionnaires with the necessary data and the lack of cooperation with some of the insurance companies operating in Kosovo. We believe that the results and arguments of this study can and should be subject to debate and prompt further studies in this field.

In conclusion, it can be said that the paths that lead us to more effective use of risk management models for insurance companies is the education of leading managers of such companies on the importance and necessity of the managerial function.

\section{References}

ABI (2000) 'Insurance: Facts, Figures and Trends', Association of British Insurers.

BQK (2014); "Raporti i stabilitetit financiar", Prishtinë Janar, Nr. 04.

BQK, "Raporti vjetor 2012", Prishtinë 2013.

BQK, "Rregullore mbi depozitimin e aseteve si garancë, mjaftueshmërisë së kapitalit, raportimin financiar, menaxhimin e riskut, investimeve dhe likuiditetin", neni 8, Prishtinë Dhjetor 2011. 
Gashi, Sherif (2011), "Analiza e tregut të sigurimeve", Prishtinë.

Gazeta Zyrtare e UNMIK-ut/Dir/1999/3, Nëntor 1999, fq. 448-450, volumi 2/99.

Griffin, W.R., (1990,) "Management", Edicioni i 3-të, Houghton Miffin Company, Boston.

Lam, J. (2003); "Enterprise risk management: From incentives to controls", Wiley, SHBA.

Sandstrom, Arne (2007), "SOLVENCY - a historical review and some pragmatic solutions", Swedish Insurance Federation, Stokholm

Shoqata e Sigurimeve të Kosovës, "Buletini i Sigurimeve", Revistë periodike, nr. 1, Qershor 2012.

Vaughan Emmett J. dhe Vaughan Therese M. (2004); "Fundamentals of risk and insurance",Wiley, SHBA.

Këshilli Kombëtar për Integrim Evropia (2013) "Tryeza tematike për ekonomi, financa dhe statistika - Kosova 2020", Raporti, Prishtinë Maj.

KPMG (2002), Study into the methodologies to assess the overall financial position of an insurance undertaking from the perspective of prudential supervision,

http://europa.eu.int/comm/internal_market/insurance/docs/solvency/solvency2-study-kpmg_en.pdf. 